\title{
Identification of methyl jasmonate-responsive genes in sugarcane using cDNA arrays
}

\author{
Vicente E. De Rosa Jr. ${ }^{1,2}$, Fábio T. S. Nogueira ${ }^{1,2}$, Marcelo Menossi ${ }^{1,2}$, Eugênio C. Ulian ${ }^{3}$ and Paulo Arruda ${ }^{1,2, *}$ \\ ${ }^{1}$ Centro de Biologia Molecular e Engenharia Genética, Universidade Estadual de Campinas (UNICAMP), 13083-875, Campinas, SP, Brazil; \\ ${ }^{2}$ Departamento de Genética e Evolução, Instituto de Biologia, Universidade Estadual de Campinas (UNICAMP), CP 6010, 13083-875, Campi- \\ nas, SP, Brazil; ${ }^{3}$ Centro de Tecnologia Canavieira, 13400-970, Piracicaba, SP, Brazil; * Corresponding author: parruda@unicamp.br \\ Received: 1/2/2004, Accepted: 11/03/2005
}

Jasmonic acid (JA) and its ester methyl jasmonate (MeJA) are linolenic acid-derived signaling molecules involved in plant development and stress responses. MeJA regulates gene expression at transcription, RNA processing and translation. We investigated the changes in gene expression in sugarcane leaves exposed to MeJA using cDNA arrays. Total RNA isolated at $0,0.5,1,3,6$, and $12 \mathrm{~h}$ following MeJA treatment was labeled with $\alpha-{ }^{33} \mathrm{P}-\mathrm{dCTP}$ and hybridized to nylon filters containing 1,536 cDNA clones. A significant increase in gene expression in response to MeJA was detected for both novel and well known stress-related genes, while genes participating in photosynthesis and carbohydrate assimilation were down-regulated. Searches for conserved domains in unknown proteins and digital mRNA expression profile analysis revealed putative new stress-related proteins up-regulated by MeJA and the tissues where the MeJA-regulated genes are preferably expressed.

Keywords: cDNA array, expression profiling, methyl-jasmonate, signaling molecules, sugarcane.

Identificação de genes responsivos ao metil-jasmonato em cana-de-açúcar usando arranjos de cDNA: $\mathrm{O}$ ácido jasmônico (JA) e seu éster metil-jasmonato (MeJA) são moléculas sinalizadoras derivadas do ácido linolênico e estão envolvidas no desenvolvimento da planta e na resposta aos estresses. MeJA regula a expressão gênica ao nível transcricional, do processamento do RNA e da tradução. Investigamos as mudanças na expressão gênica em folhas de cana-de-açúcar expostas ao MeJA usando arranjos de cDNA. O RNA total isolado a 0, 0,5, 1, 3, 6 e 12 horas após o tratamento com MeJA foi utilizado para a síntese de sondas contendo $\alpha-{ }^{33} \mathrm{P}-\mathrm{dCTP}$, as quais foram, posteriormente, hibridizadas em membranas de náilon contendo 1.536 clones de cDNA. Um aumento significativo na expressão gênica em resposta ao MeJA foi detectado em genes que respondem a estresses e também em genes com função desconhecida, enquanto os genes que participam da fotossíntese e da assimilação de carboidrato foram reprimidos. A busca por domínios conservados em proteínas desconhecidas e a análise digital do perfil de expressão de mRNA revelaram possíveis proteínas novas relacionadas a estresses induzidas por MeJA e os tecidos onde os genes regulados por MeJA são preferivelmente expressos.

Palavras-chave: arranjos de cDNA, cana-de-acúcar, metil-jasmonato, moléculas sinalizadoras perfil de expressão gênica.

\section{INTRODUCTION}

Jasmonic acid (JA) and its methyl ester (MeJA) are signaling molecules involved in several physiological process in plants, including flower and fruit development, secondary metabolite accumulation, senescence, and responses to abiotic and biotic stress (Creelman and Mullet, 1997; Devoto and Turner, 2003). The jasmonate pathway is activated by external stimuli such as UV radiation, wounding, systemin, elicitors and others (Creelman and Mullet, 1997; Devoto and Turner, 2003). Following its synthesis, MeJA influences the expression of several genes, altering the abundance of their corresponding polypeptides. A positive feedback mechanism is assumed to auto-regulate jasmonate biosynthesis since the expression of several genes of the JA-pathway, such as those encoding lipoxygenase (LOX) and allene oxide synthase (AOS), is increased by MeJA treatment (Bell and Mullet, 1993; Sivasankar at al., 2000).

Several regulatory components of the signaling pathway mediated by MeJA have been identified. For example, COI1, a protein containing an F-box motif and leucine-rich 
repeats, is implicated in ubiquitin-mediated proteolysis and wound signaling (Devoto et al., 2002), whereas ORCA3 is an APETALA2 (AP2)-domain transcription factor that regulates terpenoid indole alkaloid biosynthesis (van der Fits and Memelink, 2000).

Most studies on the effects of MeJA on gene expression have been carried out using Arabidopsis thaliana as a model (Mandaokar et al., 2003). There is little information of MeJA effects on gene expression in agronomical crops growing in tropical environments, such as sugarcane.

We took advantage of the existence of a large collection of sugarcane ESTs (SUCEST; http://sucest.lad.ic.unicamp.br/ public) to evaluate the gene expression profiles following MeJA treatments using cDNA arrays, an approach already successfully used to identify genes differentially expressed in response to MeJA and stress conditions in plants (Sasaki et al., 2001; Nogueira et al., 2003). The SUCEST database contains over 260,000 ESTs from different sugarcane libraries representing around 32,000 putative unique genes (Vettore et al., 2001). Interestingly, almost $20 \%$ of the annotated genes in the SUCEST database was proposed to function as signaling factors and stress-related proteins (Vettore et al., 2003).

In this work we analyzed the effects of MeJA on the expression profiles of 1,536 random sugarcane cDNA clones from the SUCEST database. The putative roles of the identified genes are discussed based on their annotated functions, tissue expression profile and domain analysis.

\section{MATERIAL AND METHODS}

Plant material and MeJA treatment: Sugarcane one-eyed seed sets (cv. SP80-3280, Copersucar, Brazil) were planted in $200 \mathrm{ml}$ plastic cups containing a commercial planting mix (Plantmax, Eucatex), plus a commercial fertilizer, and cultivated for 20 days under greenhouse conditions. The plantlets were subsequently transferred to a growth chamber at $26^{\circ} \mathrm{C}$ on a $16 \mathrm{~h} / 8 \mathrm{~h} \mathrm{light} /$ dark cycle with a photon flux density of $70 \mu \mathrm{E} \cdot \mathrm{m}^{-2} \cdot \mathrm{s}^{-1}$. Plantlets were then sprayed with a $100 \mu$ mol. $\mathrm{L}^{-1}$ MeJA solution. Control plantlets were treated with distilled water. Leaves were collected $0,0.5,1,3,6$ and $12 \mathrm{~h}$ after exposure to MeJA and immediately frozen in liquid nitrogen. Six plantlets were used for each time point.

High-density filter arrays and probe preparation: Sixteen 96well plates containing sugarcane cDNA clones (Vettore et al., 2001) were randomly sampled from the following sugarcane cDNA libraries: heat and cold-treated and untreated callus (CL6), plantlets inoculated with Herbasperillum rubrisubalbicans (HR1) or Acetobacter diazotroficans (AD1), and leaf roll (LR1). A total of 1,536 cDNAs clones were fixed onto sets of two high-density filters $(85 \mathrm{~mm} x$ $125 \mathrm{~mm}$ ) using a hand-held tool with a 96-pin printhead (V\&P-Scientific, USA) in a $4 \times 4$ array configuration (768 cDNAs/filter).

To estimate the level of gene redundancy, two strategies were adopted. Initially, the 1,536 EST clones were compared with each other using default parameters of the CAP3 assembler (Huang and Madan, 1999) that allowed similar sequences to assembly in contigs. Subsequently, the similarities between these contigs and sequences in the NCBI nt were retrieved using the BLASTN algorithm (http: //www.ncbi.nih.gov/blast). Using this methodology, 1,428 putative unique genes were estimated to be spotted on the filters ( $8 \%$ redundancy).

Total RNA was isolated from sugarcane leaves using Trizol Reagent (Invitrogen, USA), according to the manufacturer's instructions. For hybridizations, $30 \mu \mathrm{g}$ of total RNA was reverse transcribed with Superscript II (Invitrogen, USA) using $100 \rho$ mol of the dT18V primer, $\alpha{ }^{3}{ }^{33} \mathrm{P}-\mathrm{dCTP}$ (sp. act. $3000 \mathrm{Ci}^{\mathrm{mmol}}{ }^{-1}$ ) and unlabeled dATP, dGTP, dTTP and dCTP $\left(1 \mathrm{mM}\right.$ each) for $20 \mathrm{~min}$ at $42^{\circ} \mathrm{C}$. The cDNA probes were purified using ProbeQuant G-50 micro columns according to the manufacturer's instructions (Amersham Biosciences, USA). Variations in the amount of DNA in the spots were estimated by hybridizing the filters with an oligonucleotide probe that hybridize to the $A m p$ 'gene of the pSPORT1 vector used in the construction of SUCEST cDNA libraries. This probe was synthesized using the primers 5'-GTGGTCCTGCAACTTTATCCGC-3' and 5'-TAGACTGGATGGAGGCGGATAA-3' in the presence of $\alpha-{ }^{33} \mathrm{P}-\mathrm{dCTP}$ as described by J.D. McPherson (http://www.tree.caltech.edu/protocols/ overgo.html.). Only replicate filters with coefficients of variation $(\mathrm{CV})<10 \%$ were used for further analysis.

Data analysis: All spot signals were quantified using ArrayVision $^{\mathrm{TM}}$ software (Imaging Research, Canada) and the local background was subtracted automatically. To normalize the variation among replicate filters, the signal intensity of each spot was calculated as a ratio of the average intensity of all spots on each filter (Schummer et al., 1999). The signal variation between replicate spots on each filter was estimated as the ratio between their signal intensities. Additionally, 12 spots representing the empty plasmid vector were used in each filter to assess background hybridization. Only those 
spots with signal intensities higher than the average nonspecific signal intensity plus two standard deviations (SD) for three or more arrays were considered for further analysis. The signal intensity values of replicate spots on each filter were averaged and used to calculate the expression ratios between MeJA-treated and untreated samples. To establish the threshold in which a given spot displayed and altered gene expression, the average and the SD of the expression ratios ( $\log _{2}$ transformed) for each time point after MeJA treatment were estimated. A significant expression ratio threshold of at least $2 \mathrm{SD}$ above or below the average expression ratio for each time point was used $(\mathrm{p}<0.05)$. The relative expression of each spot was calculated using the time point that showed the maximum or minimum ratio (showed as fold in the Table 1) from two independent replicate experiments.
RNA-blot analysis: RNA-gel blot analysis was carried out according to Nogueira et al. (2003). Total RNA from a new set of MeJA-treated and untreated plantlets were isolated and the cDNA clone inserts were used as probes for RNA gel-blot hybridization. RNA-gel blot hybridization was done according to the protocol supplied with Hybond $\mathrm{N}+$ nylon filters (Amersham Biosciences, USA). The hybridized filters were exposed to imaging plates for $48 \mathrm{~h}$ and the digitized images were quantified using Image Gauge software v. 3.12 (Fujifilm, Japan).

Bioinformatics: The cDNAs encoding the MeJA-induced or -repressed genes were completely sequenced and analyzed for similarity with the non-redundant GenBank protein database using the BLASTX algorithm. For conserved

Table 1. Expression ratios and sequence similarities of MeJA-responsive sugarcane cDNAs

\begin{tabular}{|c|c|c|c|c|c|}
\hline Clone ID & Fold $^{\mathrm{a}}$ & Accession & Description $^{\mathrm{b}}$ & E-value & Function $^{\mathrm{c}}$ \\
\hline \multicolumn{6}{|l|}{ Up-regulated } \\
\hline SCCCCL6002G04 & 12.6 & CAB86383 & AOS & 0.0 & JA biosynthesis \\
\hline SCCCHR1003H09 & 43.3 & AAK52316 & Serine carboxipeptidase & E-111 & Secondary metabolism \\
\hline SCCCHR1002A11 & 8.0 & S39502 & VSP & E-29 & Nitrogen storage \\
\hline SCCCCL6002E02 & 4.0 & AAK95148 & 60S ribosomal L4 & E-101 & Protein synthesis \\
\hline SCCCCL6004C08 & 3.5 & AAK95148 & 60S ribosomal L22 & $2 \mathrm{E}-23$ & Protein synthesis \\
\hline SCCCCL6003E06 & 2.9 & P20080 & PPIASE & $6 \mathrm{E}-16$ & Protein metabolism \\
\hline SCCCAD1001C08 & 3.5 & AAC49821 & Peroxidase & E-100 & Stress response \\
\hline SCACCL6006G09 & 3.1 & JC6171 & LEA-like & $5 \mathrm{E}-26$ & Stress response protein \\
\hline SCCCCL6002H05 & 3.4 & P41152 & HSF1 & $6 \mathrm{E}-30$ & Transcriptional regulation \\
\hline SCCCCL6004F11 & 3.3 & BAB12694 & Putative ZINC finger & $3 \mathrm{E}-56$ & Transcriptional regulation \\
\hline SCACCL6010C08 & 3.5 & NP_913180 & kinase protein & $2 \mathrm{E}-40$ & Signal transduction \\
\hline SCCCAD1001B06 & 2.8 & BAB'92816 & Unknown & $8 \mathrm{E}-47$ & Unknown \\
\hline SCCCCL6002H10 & 14.3 & --- & No hit & -- & Unknown \\
\hline SCACCL6006G07 & 3.4 & --- & No hit & --- & Unknown \\
\hline SCCCHR1003H01 & 7.0 & --- & No hit & --- & Unknown \\
\hline \multicolumn{6}{|l|}{ Down-regulated } \\
\hline SCCCHR1002D08 & 0.4 & P23993 & PSAL & 7E-91 & Photosynthesis \\
\hline SCACCL6007G08 & 0.2 & BAA21653 & PPDK & $8 \mathrm{E}-96$ & Photosynthesis \\
\hline SCCCHR1004H08 & 0.2 & AAK08655 & Senescence-associated prot & $7 \mathrm{E}-48$ & Senescence \\
\hline SCCCAD1002H04 & 0.1 & NP_777096 & PUMP & E-42 & Stress response \\
\hline SCACCL6010F10 & 0.4 & AAN 86274 & DnaK & 0.0 & Stress response; transport \\
\hline SCCCCL6005F03 & 0.5 & AAK11734 & STY kinase & $2 \mathrm{E}-17$ & Signal transduction \\
\hline SCCCCL6005H06 & 0.2 & BAC57307 & Putative kinase & $3 \mathrm{E}-87$ & Signal transduction \\
\hline SCCCHR1002H12 & 0.3 & NP_564946 & Putative kinase & E-152 & Signal transduction \\
\hline SCCCCL6003F04 & 0.3 & AAL 58201 & Putative ATP $(\mathrm{GTP})$ protein & E-133 & Unknown \\
\hline SCCCCL6001A05 & 0.1 & ---- & No hit & ---- & Unknown \\
\hline SCCCCL6003G09 & 0.2 & ---- & No hit & ---- & Unknown \\
\hline
\end{tabular}

a Values represent the maximum or minimum average expression ratio of that of control (untreated).

${ }^{\mathrm{b}}$ Putative identity of cDNA based on sequence similarity searches with known protein sequences in GenBank using the BLASTX algorithm. No hit proteins have no similarity to proteins and unknown proteins share similarity to proteins of unknown function in the GenBank database

${ }^{c}$ Putative functions based on the similarity with known proteins in GenBank databases. 
domain analysis, the unknown protein sequences were analyzed using the RPS-BLAST algorithm, Pfam (Bateman et al., 2000) and SMART (Schultz et al., 2000) databases. Only domains with minimum E-value $<$ than $10^{-5}$ were considered for further studies.

Digital mRNA expression profile: For digital mRNA expression profile analysis, 25 SUCEST cDNA libraries (Vettore et al., 2001) were grouped into seven library pools, as follows: nitrogen fixing bacteria infected plants (I) - AD1 and HR1; meristematic tissues (M) - AM1, AM2, LB1 and LB2; floral organs (F) - FL1, FL3, FL4, FL6 and FL8; Leaves (L) - LV1, LR1 and LR2; Root (R) - RT1, RT2 and RT3; Seeds (Sd) - SD1 and SD2; Stem (St) - ST1, ST3, $\mathrm{SB1}$, RZ1, RZ2 and RZ3. The relative abundance of MeJAinduced and/or -repressed genes was estimated based upon the number of ESTs in a given library pool (Vettore et al., 2001) divided by the total number of ESTs in that library pool. A statistical test (Audic and Claverie, 1997) was used to calculate the probability for a gene to be equally expressed in two different conditions given the observed distribution of EST counts. Small probabilities ( $p$-values) are associated with asymmetrical distributions characterizing differentially expressed genes. ESTs associated with $p$-values $<0.05$ of being expressed at the same level in the two library pools were classified as being organ/tissue-enriched genes.

Accession numbers: The sequence data described in this paper are available in GenBank (accession numbers CA095814 to CA120047). The array data described here were submitted to the Gene Expression Omnibus (GEO) under accession number GSE1546.

\section{RESULTS AND DISCUSSION}

cDNA arrays: High-density nylon filters containing 1,536 random sugarcane cDNAs from SUCEST (Vettore et al., 2001) were constructed according to the procedure described by Nogueira et al., (2003). Each filter contained replicate spots whose signal intensities variation ranged from 0.5 to 2.0 for the majority of spots (data not shown). Twenty-six MeJA-responsive genes ( $1.8 \%$ of total) were identified in two independent experiments. Figure 1 shows scatter plots of the expression ratios of MeJA-treated versus control plantlets. Comparison of the signal ratio intensities between the treated and untreated probes yielded a minimum R-value of 0.83 , indicating that the transcript steady-state expression of most ESTs was unchanged after exposure to MeJA. To

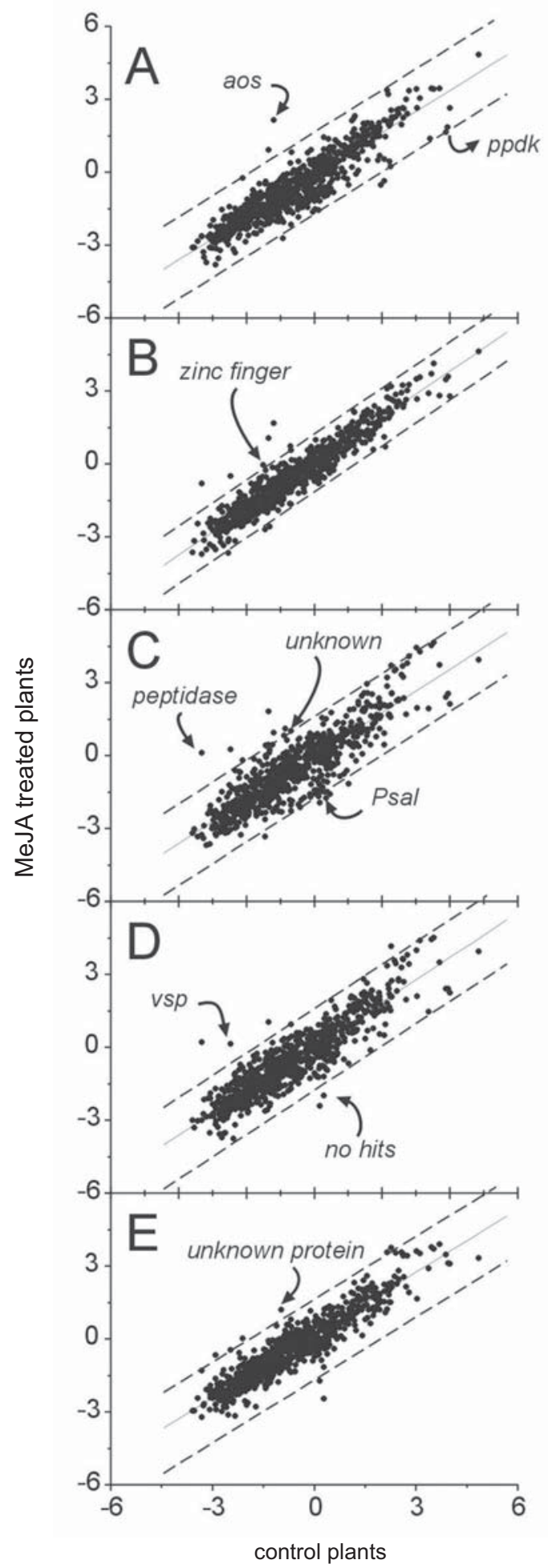

Figure 1. Scatter plots of the expression ratios of 1,536 sugarcane cDNAs. Each point in the scatter plot corresponds to a single cDNA. The hybridization signals for each spot were $\log _{2}$ transformed and plotted with the signals from control plants on the $\mathrm{x}$-axis and those from MeJA-treated plants on the y-axis. Filter hybridizations were done with $\alpha{ }^{33} \mathrm{P}$ labeled cDNA probes obtained from the total RNA of MeJA-treated and -untreated plants after 0.5 (A), 1 (B), 3 (C), 6 (D), and 12 (E) h of exposure. 
validate the array data, nine MeJA-induced or repressed genes were analyzed by RNA-gel blot. Figure 2 shows the expression profiling of RNA-gel blots. In general there is a high consistency between the two data sets.

MeJA-responsive genes in sugarcane: Twenty-six MeJAresponsive cDNAs were identified, 15 of which $(57 \%)$ were up-regulated and 11 were down-regulated (table 1). Among the up-regulated genes those encoding proteins involved in different pathways included: allene oxide synthase (AOS), that catalyzes the first specific step in the octadecanoid pathway (Bell and Mullet, 1993; Sivasankar et al., 2000) a serine carboxypeptidase-like enzyme that catalyzes the final reaction in the formation of sinapoylmalate (Shirley et al.,

Expression profiles of RNA blot analysis

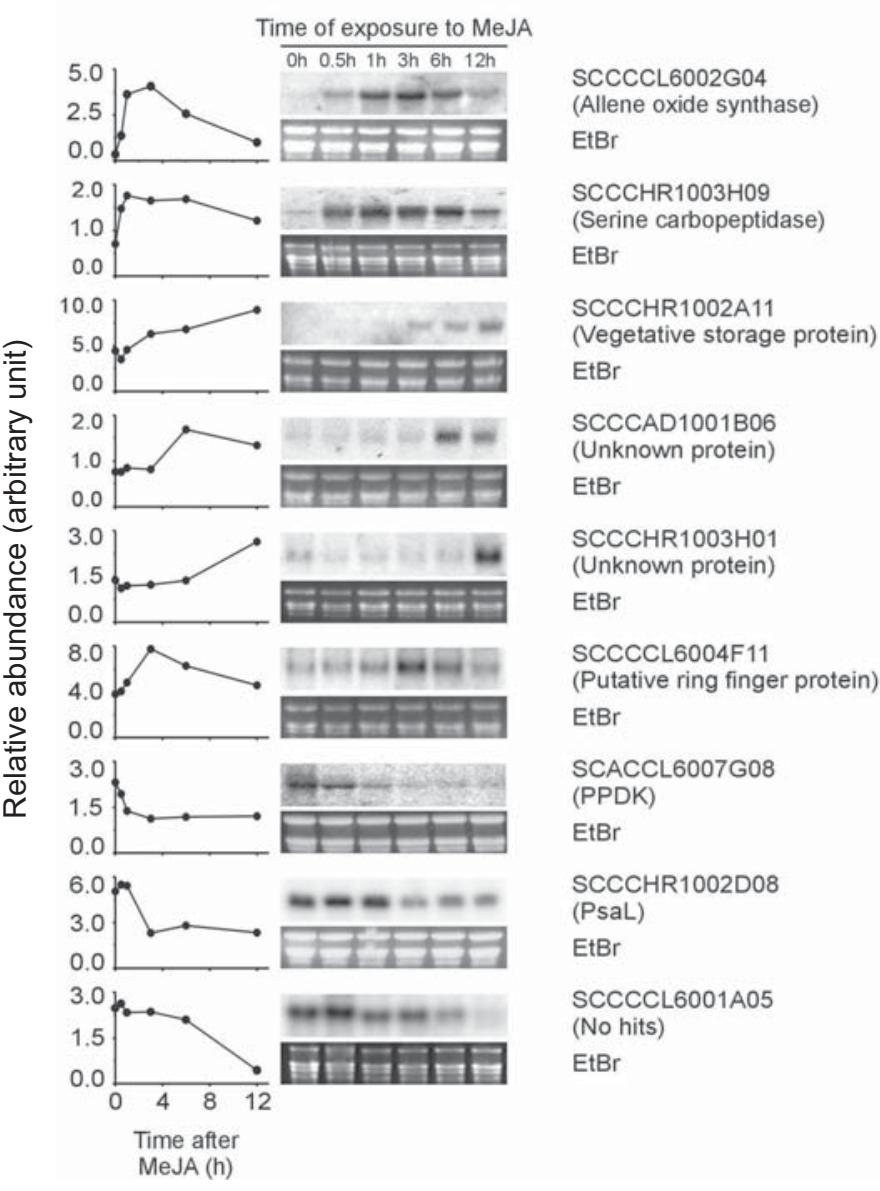

Figure 2. RNA-gel blot analysis of MeJA up- and down-regulated cDNAs identified in the cDNA arrays. The time points of MeJA treatment $(0,0.5,1,3,6$ and $12 \mathrm{~h})$ are indicated above each lane in the RNA-blots. The graphs on the left show the kinetics of up- and down- regulation observed for each gene, based on the RNA blots. Ten micrograms of total RNA were used for all samples.
2001); the vacuolar glycoprotein acid phosphatase (VSP) that has been shown to be involved in adaptative response (Staswick, 1994); 60S ribosomal L4 and L22 proteins implicated in stress response (Nakatogawa and Ito, 2002; Zengel et al., 2003); peptidyl-prolyl cis-trans isomerases (PPIASE) that catalyze the interconversion of cis and trans rotamers of amine bonds adjacent to proline (Himukai et al., 1999; Shaw, 2002); a peroxidase (POX) similar to Class III plant peroxidases induced by wounding (Curtis et al., 1997) and pathogen attack (Chittoor et al., 1997); a late embryogenesis abundant (LEA) protein that has been shown to be up-regulated by water stress (Xu et al., 1996); a heat shock factor protein (HSFA1) involved in the transcription regulation of the heat shock genes (Wu, 1995).

A number of up-regulated unknown proteins were also identified. Among these are the protein encoded by EST SCCCCL6004F11 (table 1), that contains a putative C-x8-C$\mathrm{x} 5-\mathrm{C}-\mathrm{x} 3-\mathrm{H}$ type zinc finger domain (table 2 ) and a putative protein kinase domain.

Several metabolic processes, including photosynthesis, have been reported to be negatively regulated by MeJA (Creelman and Mullet, 1997). We identified down-regulated genes that are involved in photosynthesis, stress response and senescence, as well as genes that have not previously been reported to be regulated by MeJA (table 1). Among these are genes encoding a photosystem I reaction center core protein (PSAL); a pyruvate phosphate dikinase (PPDK) that catalyzes the ATP- and Pi-dependent formation of phosphoenolpyruvate (Shinozaki and Shinozaki, 1997); a senescence-associated protein (Huang et al., 2001); an uncoupling mitochondrial protein (PUMP) that is involved in oxidative stress response (Brandalise et al., 2003) and three protein kinases. We also identified down-regulated unknown proteins. Among these is an ATP (GTP)-binding domain-containing protein (table 2).

Domain analysis: Searches for conserved domains in MeJAregulated proteins having no similarity to proteins in the GenBank identified four domains that could be involved in stress adaptation and signal transduction (table 2). The protein encoded by EST SCCCAD1001B06 revealed a heavy metal-associated domain found in a number of heavy metal-detoxifying proteins. The protein encoded by EST SCCCCL6001A05 present a peptide with a DUF domain found in proteins of cyanobacterium and in the chloroplasts of algae. The protein encoded by SCACCL6006G07 has a formin domain found in proteins involved in controlling 
Table 2. Conserved domains of MeJA-regulated sugarcane unknown and no hit proteins.

\begin{tabular}{llllll}
\hline Clone ID & Domain & Accession $^{\mathrm{a}}$ & E-value & Similarity & Putative function $^{\mathrm{b}}$ \\
\hline SCCCAD1001B06 & Heavy-metal domain & pfam00403 & $3 \mathrm{E}-22$ & $39 \%$ & Metal ion transport \\
SCCCCL6001A05 & DUF domain & pfam04481 & $6.1 \mathrm{E}-12$ & $69 \%$ & Unknown \\
SCACCL6006G07 & Formin & pfam02181 & $9 \mathrm{E}-07$ & $15 \%$ & Cytoskeletal rearrangement \\
SCCCHR1003H01 & LEA_3 & pfam03242 & $1 \mathrm{E}-06$ & $56 \%$ & Hydric stress tolerance \\
\hline
\end{tabular}

${ }^{a}$ Accession of each domain sequence was obtained by using the RPS-BLAST algorithm and the Pfam and SMART databases.

bPutative functions based on similar domains described in SMART and Pfam domain family databases.

cytoskeleton rearrangements. The protein encoded by EST SCCCHR1003H01 contains a LEA domain found in stressresponsive proteins (Xu et al., 1996).

Digital mRNA expression profile: EST frequencies in a standard cDNA library can be used to infer levels of gene expression (Vettore et al., 2003). This is based on the fact that the number of ESTs from a given gene is proportional to the abundance of its mRNA. To determine the tissue/ organs in which MeJA-responsive genes are preferentially expressed, we used a digital mRNA expression profile analysis to identify significant changes in EST frequencies among sugarcane library pools.

Analysis of the 26 MeJA-responsive genes revealed 14 SAS (Vetore et al., 2003) displaying organ-enriched expressions when $p \leq 0.05$ ( $p$, a probability of the compared EST abundances being different by chance) was applied (Table 3). For example the SAS encoding VSP was significantly more expressed in roots when compared to floral organs, leaves, meristem and seeds (table 3 ). This finding corroborates to the role of VSPs, which accumulate in roots as a nitrogen store that can be used to initiate regrowth (Rossato et al., 2002). Among the differentially expressed genes, only the one encoding a putative STY kinase and the SAS encoding DnaK were preferentially expressed in a unique sugarcane organ. The former was more expressed in roots whereas the later was significantly more represented in stems (table 3 ). The SAS encoding AOS enzyme was preferentially expressed in meristematic tissues when compared to flowers or seeds. This is consistent with

Table 3. Number of ESTs and significance levels ( $p$-values) from digital mRNA expression profile of identified MeJA responsive genes.

\begin{tabular}{|c|c|c|c|c|c|c|c|c|c|}
\hline \multirow{2}{*}{$\mathrm{SAS}^{\mathrm{a}}$} & \multirow{2}{*}{ Description } & \multirow{2}{*}{ Organ $^{b}$} & \multicolumn{7}{|c|}{ SAS EST number ${ }^{c}$} \\
\hline & & & Root & Stem & Meristem & Leaves & Infected & Seed & Flower \\
\hline SCEQLB1067F01 & VSP & Root & 9 & $7^{\mathrm{NS}}$ & $3^{*}$ & $0^{*}$ & $3^{\mathrm{NS}}$ & $0^{*}$ & $3^{*}$ \\
\hline SCJFLR1073H09 & Kinase & Root & 74 & $59^{*}$ & $21^{*}$ & $6^{*}$ & $22^{*}$ & $1^{*}$ & $21^{*}$ \\
\hline SCCCRZ1002G01 & DnaK & Stem & $44^{*}$ & 152 & $79^{*}$ & $29^{*}$ & $50^{*}$ & $17^{*}$ & $109^{*}$ \\
\hline SCAGLR1043E04 & AOS & Meristem & $1^{\mathrm{NS}}$ & $2^{*}$ & 8 & $1^{\mathrm{NS}}$ & $4^{\mathrm{NS}}$ & $1^{\mathrm{NS}}$ & $2^{*}$ \\
\hline SCCCLR1C02E07 & $\mathrm{L} 22$ & Meristem & $0^{*}$ & $4^{*}$ & 11 & $5^{\mathrm{NS}}$ & $4^{\mathrm{NS}}$ & $2^{\mathrm{NS}}$ & $7^{\mathrm{NS}}$ \\
\hline SCCCCL3140B12 & L4 & Leaf & $1^{\mathrm{NS}}$ & $2 *$ & $2^{\mathrm{NS}}$ & 4 & $4^{\mathrm{NS}}$ & $0^{\mathrm{NS}}$ & $3^{\mathrm{NS}}$ \\
\hline SCACCL6007G08 & PPDK & Leaf & $0^{\mathrm{NS}}$ & $0^{*}$ & $0^{\mathrm{NS}}$ & 2 & $1^{\mathrm{NS}}$ & $0^{\mathrm{NS}}$ & $0^{*}$ \\
\hline SCQGLR2025B12 & PSAL & Leaf & $0^{*}$ & $10^{\mathrm{NS}}$ & $1^{*}$ & 5 & $4^{\mathrm{NS}}$ & $20^{\mathrm{NS}}$ & $2^{*}$ \\
\hline SCCCHR1003H01 & No hit & Leaf & $5^{\mathrm{NS}}$ & $12^{\mathrm{NS}}$ & $6^{*}$ & 10 & $10^{\mathrm{NS}}$ & $7^{\mathrm{NS}}$ & $5^{*}$ \\
\hline SCQSRT2036C09 & No hit & Infected & $2^{\mathrm{NS}}$ & $5^{\mathrm{NS}}$ & $3^{\mathrm{NS}}$ & $1^{\mathrm{NS}}$ & 6 & $2^{\mathrm{NS}}$ & $3^{*}$ \\
\hline SCCCCL6003F04 & ATP (GTP)-binding & Stem & $1^{*}$ & 13 & $3^{*}$ & $3^{\mathrm{NS}}$ & $2^{\mathrm{NS}}$ & $2^{\mathrm{NS}}$ & $8^{\mathrm{NS}}$ \\
\hline SCJFLR1073A02 & Kinase & Seed & $0^{\mathrm{NS}}$ & $0^{\mathrm{NS}}$ & $0^{\mathrm{NS}}$ & $0^{\mathrm{NS}}$ & $0^{\mathrm{NS}}$ & 1 & $0^{*}$ \\
\hline SCCCCL4005F05 & Kinase & Seed & $0^{\mathrm{NS}}$ & $0^{*}$ & $0^{\mathrm{NS}}$ & $0^{\mathrm{NS}}$ & $2^{\mathrm{NS}}$ & 2 & $1^{\mathrm{NS}}$ \\
\hline SCCCAD1001B06 & Unknown & Seed & $0^{\mathrm{NS}}$ & $1^{\mathrm{NS}}$ & $0^{\mathrm{NS}}$ & $0^{\mathrm{NS}}$ & $0^{\mathrm{NS}}$ & 2 & $0^{*}$ \\
\hline cDNA library size & (Total number of ESTs) & & 24430 & 39116 & 52430 & 19676 & 25302 & 17106 & 49785 \\
\hline
\end{tabular}

${ }^{a}$ Sugarcane assembled sequences.

${ }^{\mathrm{b}}$ Organ in which a gene is preferentially expressed based on the $p$-values.

${ }^{c}$ EST number of each SAS in a given library pool. Because the $p$-values were obtained by using the significance test described by Audic and Claverie (1997), similar EST numbers can display different levels of significance depending on the total number of ESTs in a particular library pool (see Methods).

* Significance at $p \leq 0.05$; NS Non-significant at $p \leq 0.05$. 
localization of AOS activity in chloroplasts (Maucher et al., 2000). The SAS encoding 60S ribosomal proteins L4 and L22 was preferentially expressed in leaves and meristems when compared to roots or seeds (table 3). This is in keeping with the expression of L4 and L22 in chloroplasts of monocots (Yamaguchi and Subramanian, 2000). The SAS encoding PPDK and PSAL showed higher expression in leaves, consistent with their roles in photosynthesis.

From the six SASs encoding proteins for which no function were attributed, SAS SCCCHR1003H01 was preferentially expressed in leaves, SAS SCQSRT2036C09 was preferentially expressed in infected tissues, SAS SCCCCL6003F04 was more expressed in the stem while SASs SCCCAD1001B06, SCJFLR1073A02 and SCCCCL4005F05 were preferentially expressed in seeds.

The MeJA-differentially expressed genes identified in this study revealed new components putatively involved in signal transduction of physiological processes mediated by MeJA. Genes related to photosynthesis and carbon assimilation as well as a gene encoding a senescence-associated protein was found to be down-regulated by MeJA. The new components identified that could be involved in signal transduction and adaptation to stress included putative genes encoding ATP (GTP)-binding domain-containing proteins, kinases and zinc finger proteins. Finally, the digital mRNA expression profiles provided additional information about the identified genes, including an unknown protein preferentially expressed in roots.

Acknowledgements: The authors thank to A L. Beraldo, R. G. Angarten and A. S. Zanca for technical assistance, P. H. Fisch for help in bioinformatics, and G. Cord Neto for the critical reading of the manuscript.

\section{REFERENCES}

Audic S, Claverie JM (1997) The significance of digital gene expression profiles. Genome Res. 7:986-995.

Bateman A, Birney E, Durbin R, Eddy SR, Howe KL, Sonnhammer ELL (2000) The Pfam protein families database. Nucl. Acids Res. 28:263-266.

Bell E, Mullet JE (1993) Characterization of an Arabidopsislipoxygenase gene responsive to methyl jasmonate and wounding. Plant Physiol. 103:1133-1137.

Brandalise M, Maia IG, Borecky J, Vercesi AE, Arruda P (2003) Overexpression of plant uncoupling mitochondrial protein in transgenic tobacco increases tolerance to oxidative stress. J. Bioenerg. Biomembr. 35:203-209.

Chittoor JM, Leach JE, White FF (1997) Differential induction of a peroxidase gene family during infection of rice by Xanthomonas oryzae pv. Oryzae. Mol. PlantMicrobe Interac. 10:861-871.
Creelman RA, Mullet JE (1997) Oligosaccharins, brassinolides, and jasmonates: nontraditional regulators of plant growth, development, and gene expression. Plant Cell 9:1211-1223.

Curtis MD, Rae AL, Rusu, Harrison SJ, Manners JM (1997) A peroxidase gene promoter induced by phytopathogens and methyl jasmonate in transgenic plants. Mol. PlantMicrobe Interac. 10:326-338.

Devoto A, Nieto-Rostro M, Xie DX, Ellis C, Harmston R, Patrick E, Davis J, Sherratt L, Coleman M, Turner JG (2002) COI1 links jasmonate signaling and fertility to the SCF ubiquitin-ligase complex in Arabidopsis. Plant J. 32:457-466.

Devoto A, Turner JG (2003) Regulation of jasmonatemediated plant responses in Arabidopsis. Ann. Bot. 92: 329-337.

Himukai R, Kuzuhara T, Horikoshi M (1999) Relationship between the subcellular localization and structures of catalytic domains of FKBP-type PPIASE. J. Biochem. 126:879-888.

Huang YJ, To KY, Yap MN, Chiang WJ, Suen DF, Chen SCG (2001) Cloning and characterization of leaf senescence up-regulated genes in sweet potato. Physiol. Plant. 113: 384-391.

Huang, X.and Madan, A (1999) CAP3: A DNA sequence assembly program. Genome Res. 9:868-877.

Kenichi Yamaguchi and Alap R. Subramanian (2000) The plastid ribosomal proteins. Identification of all the proteins in the $50 \mathrm{~s}$ subunit of an organelle ribosome (chloroplast). J. Biol. Chem. 275:28466-28482.

Mandaokar A, Kumar VD, Amway M, Browse J (2003) Microarray and differential display identify genes involved in jasmonate-dependent anther development. Plant Mol. Biol. 52:775-786.

Maucher H, Hause B, Feussner I, Ziegler I, Wasternack C (2000) Allene oxide synthases of barley (Hordeum vulgare cv. Salome): tissue specific regulation in seedling development. Plant J. 21:199-213.

Nakatogawa H, Ito K (2002) The ribosomal exit tunnel functions as a discriminating gate. Cell 108:629-636.

Nogueira FTS, De Rosa VE, Menossi M, Ulian EC, Arruda P (2003) RNA expression profiles and data mining of sugarcane response to low temperature. Plant Physiol. 132:1811-1824

Rossato L, MacDuff JH, Laine P, Le Deunff E, Ourry A (2002) Nitrogen storage and remobilization in Brassica napus L. during the growth cycle: effects of methyl jasmonate on nitrate uptake, senescence, growth, and VSP accumulation. J. Exp. Bot. 53:1131-1141.

Sasaki Y, Asamizu E, Shibata D, Nakamura Y, Kaneko T, Awai K, Amagai M, Kuwata C, Tsugane T, Masuda T et al. (2001) Monitoring of methyl jasmonate-responsive genes in Arabidopsis by cDNA macroarray: Selfactivation of jasmonic acid biosynthesis and crosstalk with other phytohormone signaling pathways. DNA Res. 8:153-161

Schultz J, Copley RR, Doerks T, Ponting CP, Bork P (2000) SMART: a web-based tool for the study of genetically mobile domains. Nucl. Acids Res. 28:231-234. 
Schummer M, Ng VLV, Baumgarner RE, Nelson PS, Schummer B, Bednarski DW, Hassell L, Baldwin RL, Karlan BY, Hood L (1999) Comparative hybridization of an array of 21,500 ovarian cDNAs for the discovery of genes overexpressed in ovarian carcinomas. Gene 238: 375-385.

Shaw PE (2002) Peptidyl-prolyl isomerases: a new twist to transcription. EMBO Rep. 3:521-526.

Shinozaki K, Shinozaki KY (1997) Gene expression and signal transduction in water-stress response. Plant Physiol. 115:327-334.

Shirley AM, McMichael CM, Chapple C (2001) The sng2 mutant of Arabidopsis is defective in the gene encoding the serine carboxypeptidase-like protein sinapoylglucose: choline sinapoyltransferase. Plant J. 28:83-94.

Sivasankar S, Sheldrick B, Rothstein SJ (2000) Expression of allene oxide synthase determines defense gene activation in tomato. Plant Physiol. 122:1335-1342.

Staswick PE (1994) Storage proteins of vegetative plant tissue. Annu. Rev. Plant Physiol. Plant Mol. Biol. 45: 303-322. van der Fits L, Memelink J (2000) ORCA3, a jasmonateresponsive transcriptional regulator of plant primary and secondary metabolism. Science 289:295-297.

Vettore AL, da Silva FR, Kemper EL et al., (2003) Analysis and functional annotation of an expressed sequence tag collection for tropical crop sugarcane, Genome Res. 13: 2725-2735.

Vettore AL, da Silva FR, Kemper EL, Arruda P (2001) The libraries that made SUCEST. Genet. Mol. Biol. 24:1-7.

Wu C (1995) Heat shock transcription factors: structure and regulation. Annu. Rev. Cell Dev. Biol. 11:441-469.

Zengel JM, Jerauld A, Walker A, Wahl MC, Lindahl L (2003) The extended loops of ribosomal proteins L4 and L22 are not required for ribosome assembly or L4-mediated autogenous control. RNA-A Publication of the RNA Society 9:1188-1197.

Xu D, Duan X, Wang B, Hong B, Ho THD, Wu R (1996) Expression of a late embryogenesis abundant protein gene, HVA1, from barley confers tolerance to water deficit and salt stress in transgenic rice. Plant Physiol. 110:249-257. 